UDC 544.252.234+537.226.4

E. P. Pozhidaev ${ }^{1,2}$, S. I. Torgova ${ }^{1}$, E. M. Budynina ${ }^{1,3}$, T. P. Tkachenko ${ }^{1,2}$,

A. V. Kuznetsov ${ }^{1,2}$, V. A. Barbashov ${ }^{1}$

\title{
FERROELECTRIC SMECTIC C* PHASE WITH SUB-WAVELENGTH HELIX PITCH INDUCED IN A NEMATIC LIQUID CRYSTAL BY CHIRAL NON-MESOGENIC DOPANTS
}

${ }^{1}$ P. N. Lebedev Physical Institute, 53 Leninsky Pr., Moscow, 119991, Russia

${ }^{2}$ Moscow Aviation Institute (National Research University), 4 Volokolamskoe Sh., Moscow, 125993, Russia ${ }^{3}$ Lomonosov Moscow State University, Department of Chemistry, 1-3 Leninskie gory, Moscow, 119991, Russia E-mail: epozhidaev@ mail.ru

We report the development of chiral smectic $C^{*}\left(S m C^{*}\right)$ ferroelectric materials with a short helix pitch $p_{o}<150 \mathrm{~nm}$ obtained by mixing a nematic liquid crystal (NLC) and chiral non-mesogenic dopants. Chiral dopants are optically active lactates based on terphenyldicarboxylic acid, and the NLC is a binary eutectic mixture of phenyl- and biphenylpyrimidines. The appearance of the SmC* phase in mixtures was confirmed by dielectric, optical and electro-optical measurements. The proposed method for the elaboration of smectic $C^{*}$ material makes it possible to create innovative electro-optical media that combine the mechanical stability of $N L C$ and a high switching frequency of ferroelectric liquid crystals. The high twisting power of chiral lactates in the developed nematic matrix made it possible to obtain a satisfactory optical quality of induced SmC* in electrooptical cells that can efficiently operate up to frequency of $3 \mathrm{kHz}$.

Key words: ferroelectric liquid crystal, chiral dopants, nematic matrix, helix pitch.

DOI: $10.18083 /$ LCAppl.2020.3.26

Е. П. Пожидаев, , С. И. Торгова ${ }^{1}$, Е. М. Будынина ${ }^{1,3}$, Т. П. Ткаченко ${ }^{1,2}$, А. В. Кузнецов ${ }^{1,2}$, В. А. Барбашов

\section{СМЕКТИЧЕСКАЯ С* СЕГНЕТОЭЛЕКТРИЧЕСКАЯ ФАЗА С СУБВОЛНОВЫМ ШАГОМ СПИРАЛИ, ИНДУЦИРОВАННАЯ В НЕМАТИЧЕСКОМ ЖИДКОМ КРИСТАЛЛЕ ХИРАЛЬНЫМИ НЕМЕЗОГЕННЫМИ ДОБАВКАМИ}

\footnotetext{
${ }^{1}$ Физический институт им. П. Н. Лебедева, Ленинский пр., 53, 119991 Москва, Россия

${ }^{2}$ Московский авиационный институт, Государственный технический университет (МАИ), Волоколамское ш., 4, 125993 Москва, Россия

${ }^{3}$ Московский государственный университет им. М. В. Ломоносова, Химический факультет, Ленинские горы, д. 1, стр. 3, 119991 Москва, Россия

E-mail: epozhidaev@mail.ru
}

\begin{abstract}
Мы сообщаем о разработке хиральных смектических $C^{*}\left(\operatorname{Sm} C^{*}\right)$ сегнетоэлектрических материалов с коротким шагом спирали $p_{0}<150$ нм, полученных путем смешивания нематического жидкого кристалла (НЖК) и хиральных немезогенных соединений. Хиральные добавки представляют собой оптически активные лактаты на основе терфенилдикарбоновой кислоты, а НЖК является бинарной эвтектической смесью фенил- и бифенилпиримидинов. Возникновение $\mathrm{Sm}^{*}$ *
\end{abstract}

(C) Pozhidaev E. P., Torgova S. I., Budynina E. M., Tkachenko T. P., Kuznetsov A. V., Barbashov V. A., 2020 
диэлектрическими, оптическими и электрооптическими измерениями. Предлагаемый способ получения смектических $C^{*}$ материалов позволяет создавать инновационные электрооптические среды, сочетаюшие механическую устойчивость НЖК и высокую частоту переключения сегнетоэлектрических жидких кристаллов. Высокая закручивающая способность хиральных лактатов в разработанной нематической матрице позволила получить удовлетворительное оптическое качество индуцированных смектиков $C^{*}$ в электрооптических ячейках, которые могут эффективно работать на частотах до $3 \kappa Г$ Г.

Ключевые слова: сегнетоэлектрический жидкий кристалл, хиральные добавки, нематическая матрица, шаг спирали.

\section{Introduction}

Smectic C* ferroelectric liquid crystals (FLC's) attract attention of scientists and engineers due to their potential usage in fast display and photonic devices for different applications, operating in the microsecond range [1-3]. The simplest method to create FLC compositions with the requested properties is to add a chiral dopant into a non-chiral smectic $\mathrm{C}$ matrix $[4,5]$. It is necessary to elaborate a smectic $\mathrm{C}$ matrix with the required properties, such as the relevant phase transitions sequence, low rotational viscosity, and appropriate molecular tilt angle. Finally, it is necessary to choose a chiral dopant that provides acceptable values of the spontaneous polarization and the helix pitch of the mixture [6]. For the first time we have induced a chiral smectic $\mathrm{C}^{*}$ phase by adding a nonmesogenic chiral dopant - the diester of optical active 2-heptanol and terphenyldicarboxylic acid to the nematic liquid crystal (NLC) 5-hexyl-2-[4(octyloxy)phenyl]-pyrimidine [7]. The smectic $\mathrm{C}^{*}$ obtained in such a way can flow, allowing to restore the ferroelectric liquid crystal layer structure in electro-optical cells after the action of mechanical stress, as it happens with the cells filled with NLC. The material developed in [7] can operate only in the surface stabilized ferroelectric liquid crystal (SSFLC) mode since its helix pitch $p_{0}>1 \mu \mathrm{m}$.

The main task of this work is the elaboration of the FLC material with a short (sub-wavelength) helix pitch following the procedure described above. Such FLC materials are suitable for using in deformed helix ferroelectric (DHF) electrooptical mode [8], which is favorable for the following applications: field sequential color (FSC) displays [9-11], generation of axial-symmetric vortex light fields [12], light polarization modulation [13,14], switching of fiberoptic communication channels [15].

\section{Experimental}

\section{Elaboration of the sub-wavelength helix pitch ferroelectric smectic $C^{*}$}

As an achiral nematic matrix, two-component mixture consisting of 2-(4'-heptylbiphenyl-4-yl)-5octyl-pyrimidine (I), (BPP-87) [16] and 5-hexyl-2-[4(octyloxy)phenyl]pyrimidine (II), (PP-608) (commercial available material) was developed:

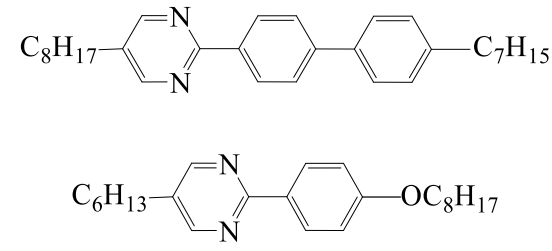

The phase diagram of the mixture is presented on the Fig. 1.

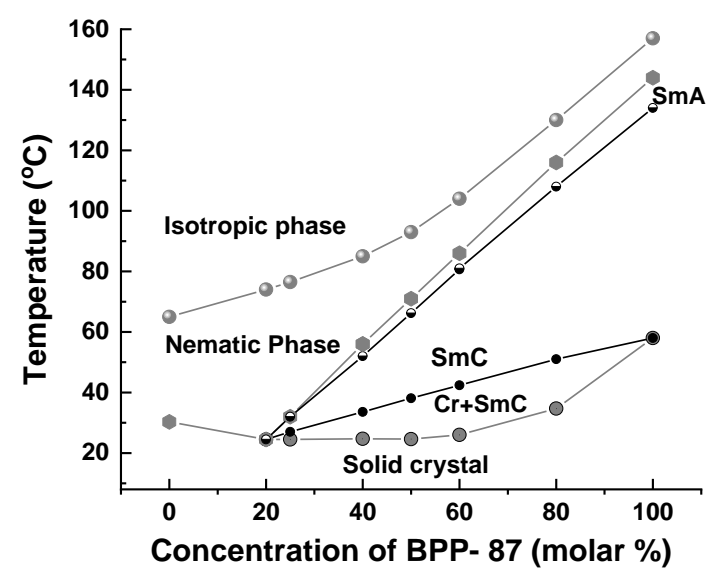

Fig. 1. Phase diagram of the mixtures of pyrimidines (I) and (II). The eutectic mixture of nematic phase is at $20 \mathrm{~mol}$ \% of compound BBP-87 and $80 \mathrm{~mol} \%$ of compound

PP-608 
Transition temperatures were detected using a MettlerToledo FP-5 thermo-stage apparatus (Greifensee, Switzerland) with a polarising Leitz microscope (Wetzlar, Germany) and via differential scanning calorimetry (DSC) by means of Perkin-Elmer DSC-7 (Waltham, Massachusetts, USA).

Esters of p-terphenyldicarboxylic acid and (S)alkan-2-yl-(S)-2-hydroxypropanoates, first described in $[17,18]$ were chosen as chiral compounds of the smectic $\mathrm{C}^{*}$ mixtures. In contrast to the synthesis used in the patent [18], chiral dopants were synthesized in this work according to the following scheme:
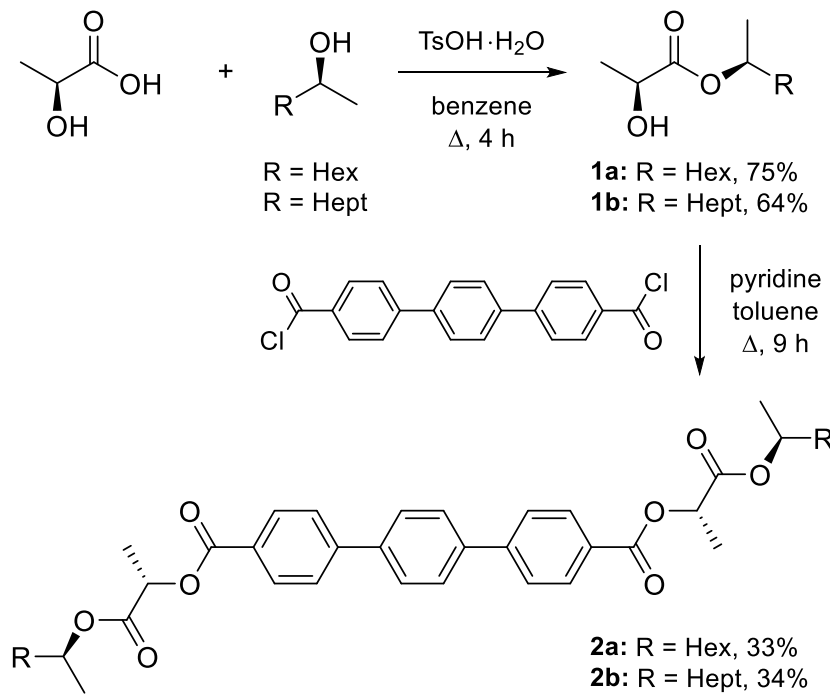

NMR spectra were acquired on Bruker Avance 600 $\mathrm{MHz}$ spectrometer at room temperature. High resolution and accurate mass measurements were carried out using Thermo Scientific LTQ Orbitrap XL mass spectrometers. Analytical thin layer chromatography (TLC) was carried out with silica gel plates (silica gel 60, F254, supported on aluminium) and visualized with UV lamp (254 nm). Column chromatography was performed on silica gel 60 (230400 mesh).

$L$-(+)-Lactic acid (85\% aqueous solution), (2S)-octan2-ol, (2S)-nonan-2-ol, $p$-terphenyl-4,4"-dicarboxylic acid are commercially available materials. 1,1':4',1"Terphenyl-4,4"-dicarbonyl dichloride was obtained from $p$-terphenyl-4,4"-dicarboxylic acid according to the procedure, described in [19].
(1S)-1-Methylheptyl (2S)-2-hydroxypropanoate (1a)<smiles>CC(=O)OC(C)C(C)O</smiles>

A mixture of $L$-(+)-lactic acid (85\% aqueous solution) (ca. $1.54 \mathrm{~g}$, $14.52 \mathrm{mmol}),(2 S)$-octan-2-ol (1.89 g, $14.52 \mathrm{mmol}$ ) and $p$-toluenesulfonic acid monohydrate (276 mg, $1.45 \mathrm{mmol}, 10 \mathrm{~mol} . \%)$ in benzene $(60 \mathrm{~mL})$ was heated under reflux with $20-\mathrm{mL}$ Dean-Stark trap for $4 \mathrm{~h}$. Reaction mixture was allowed to cool to ambient temperature and concentrated under reduced pressure. The product $\mathbf{1 a}$ was purified by column chromatography on silica gel (eluent petroleum ether - ethyl acetate 5:1).

Yield $2.20 \mathrm{~g}(75 \%)$; colorless oil.

HRMS (ESI) $m / z:[\mathrm{M}-\mathrm{H}]^{-}$Calculated for $\mathrm{C}_{11} \mathrm{H}_{21} \mathrm{O}_{3}{ }^{-}$ 201.1496; Found 201.1494.

\section{(1S)-1-Methyloctyl(2S)-2-hydroxypropanoate (1b)}<smiles>CCCCCC(C)OC(=O)C(C)O</smiles>

The substance $\mathbf{1 b}$ was synthesized similar to 1a described above. A mixture of $L$-(+)-lactic acid (85\% aqueous solution) (ca. $370 \mathrm{mg}$, $3.47 \mathrm{mmol}$ ), (2S)-nonan-2-ol (500 mg, $3.47 \mathrm{mmol}$ ) and $p$-toluenesulfonic acid monohydrate $(67 \mathrm{mg}$, $0.35 \mathrm{mmol}, 10 \mathrm{~mol}$. \%) were taken into the reaction. The product $\mathbf{1 b}$ was purified by column chromatography on silica gel (eluent petroleum ether ethyl acetate 5:1). Yield $480 \mathrm{mg}$ (64\%); colorless oil. HRMS (ESI) $\mathrm{m} / \mathrm{z}:[\mathrm{M}-\mathrm{H}]^{-}$Calculated for $\mathrm{C}_{12} \mathrm{H}_{23} \mathrm{O}_{3}{ }^{-}$ 215.1653; Found 215.1650. The chemical structure and purity of the substances $\mathbf{1 a}$ and $\mathbf{1 b}$ were confirmed by ${ }^{1} \mathrm{H}$ NMR and ${ }^{13} \mathrm{C}$ NMR spectoscopy.

Bis[(1S)-1-methyl-2-\{[(1S)-1-methylheptyl]oxy\}-2oxoethyl] 1,1':4',1"-terphenyl-4,4"-dicarboxylate (2a)

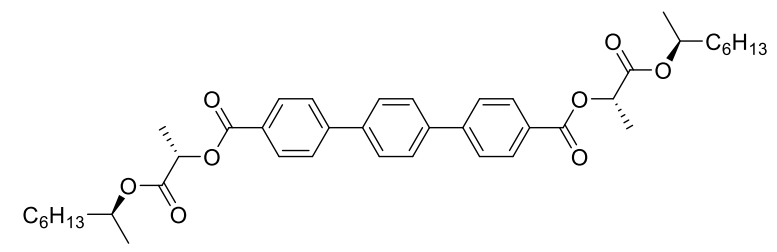

To a refluxed solution of 1,1':4',1"-terphenyl-4,4"dicarbonyl dichloride $(1.50 \mathrm{~g}, 4.22 \mathrm{mmol})$ in dry toluene $(50 \mathrm{~mL})$ the solution of $(1 S)-1$-methylheptyl (2S)-2-hydroxypropanoate $(2.13 \mathrm{~g}, 10.53 \mathrm{mmol})$ in toluene $(20 \mathrm{~mL})$ and dry pyridine $(5.4 \mathrm{ml})$ was added dropwise sequentially. The resulting mixture was heated under reflux for $9 \mathrm{~h}$. After cooling to the ambient temperature, the precipitate was filtered off and washed with ethyl acetate $(20 \mathrm{~mL})$. 
The resulting filtrate was concentrated under reduced pressure. The residue was subjected to column chromatography on silica gel (eluent petroleum ether ethyl acetate 5:1). The eluate was concentrated under reduced pressure. The subsequent recrystallization from petroleum ether afforded the desired product $\mathbf{2 a}$ as white crystals. Yield $943 \mathrm{mg}(33 \%)$.

HRMS (ESI) $m / z:[\mathrm{M}+\mathrm{H}]^{+}$Calculated for $\mathrm{C}_{42} \mathrm{H}_{55} \mathrm{O}_{8}{ }^{+}$ 687.3891; Found 687.3888.

Melting point detected by microscopy is $92.4-93.0^{\circ} \mathrm{C}$. Melting point detected via DCS is $91.86{ }^{\circ} \mathrm{C}$, melting heat is $\mathrm{J} / \mathrm{g}=44.08$

Bis[(1S)-1-methyl-2-\{[(1S)-1-methyloctyl]oxy\}-2oxoethyl] 1,1':4',1"-terphenyl-4,4"-dicarboxylate (2b)

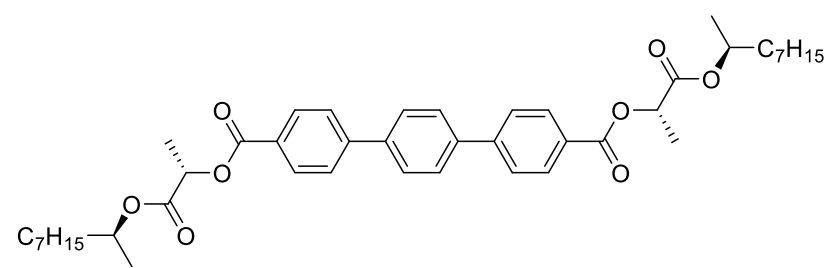

The substance $\mathbf{2 b}$ was synthesized similar to $\mathbf{2 a}$ described above. To a refluxed solution of 1,1':4',1"terphenyl-4,4"-dicarbonyl dichloride (298 mg, $0.84 \mathrm{mmol})$ in dry toluene $(10 \mathrm{~mL})$ the solution of (1S)-1-methyloctyl (2S)-2-hydroxypropanoate (416 mg, $1.93 \mathrm{mmol})$ in toluene $(5 \mathrm{~mL})$ and dry pyridine $(1.0 \mathrm{ml})$ was added dropwise sequentially, etc. The subsequent recrystallization from petroleum ether afforded the desired product $\mathbf{2 b}$ as white crystals. Yield $206 \mathrm{mg}$ (34\%).

HRMS (ESI) $m / z:[\mathrm{M}+\mathrm{H}]^{+}$Calculated for $\mathrm{C}_{44} \mathrm{H}_{59} \mathrm{O}_{8}{ }^{+}$ 715.4204; Found 715.4213.

The chemical structure and purity of the substances $\mathbf{2 a}$ and 2b were confirmed by ${ }^{1} \mathrm{H}$ NMR and ${ }^{13} \mathrm{C}$ NMR spectoscopy. Melting point detected by microscopy is 91.5-92.3 ${ }^{\circ} \mathrm{C}$. Melting point detected via DCS is $90.79^{\circ} \mathrm{C}$, melting heat is $\mathrm{J} / \mathrm{g}=68.32$.

\section{Techniques for preparation and investigations of $\mathrm{SmC}^{*}$ cells}

The FLC cells with homogeneous planar alignment were fabricated using rubbed polyimide PMDA-ODA $[20,21]$ as aligning layers that cover indium tin oxide (ITO) layers deposited onto glass substrates. The cell gap of assembled experimental cells was formed with glassy spacers and then fixed by epoxy glue. The cells were filled with FLCs in isotropic phase by capillary action.
Measurements of the helix pitch were performed with the cells that were aligned homeotropically (the helix axes of the mixtures in $\mathrm{SmC}^{*}$ phase were aligned perpendicular to the substrates). The homeotropic alignment of the mixtures has been accomplished by spin-coating glass plates with 40-nm-thick layer of stearic acid chromium salt followed by heating at temperature $100{ }^{\circ} \mathrm{C}$ for $10 \mathrm{~min}$ [22]. The helix pitch was measured due to angular dependence of selective reflection from the SmC* phase [23].

Phase transition temperatures were determined using differential scanning calorimetry (DSC) and polarizing microscopy (POM), which also allows to take micro-photographs of liquid crystal textures. For this purpose, a polarizing microscope POLAM-P-312 was used.

Spontaneous polarization $\boldsymbol{P}_{s}$ was measured using the field-reversal method [24], and rotational viscosity $\gamma_{\varphi}$ was evaluated from the measurements of the electrooptical response time and $\boldsymbol{P}_{s}$, as it has been reported in [25].

\section{Results and discussion}

A variety of mixtures have been developed containing a binary eutectic nematic matrix (ENLC) and the synthesized chiral dopants of various concentrations. All such mixtures, which have been used to construct the phase diagram at mixing of ENLC with (2a) or (2b) compounds (Fig. 2), were investigated by DSC, POM, dielectric and electrooptical methods.

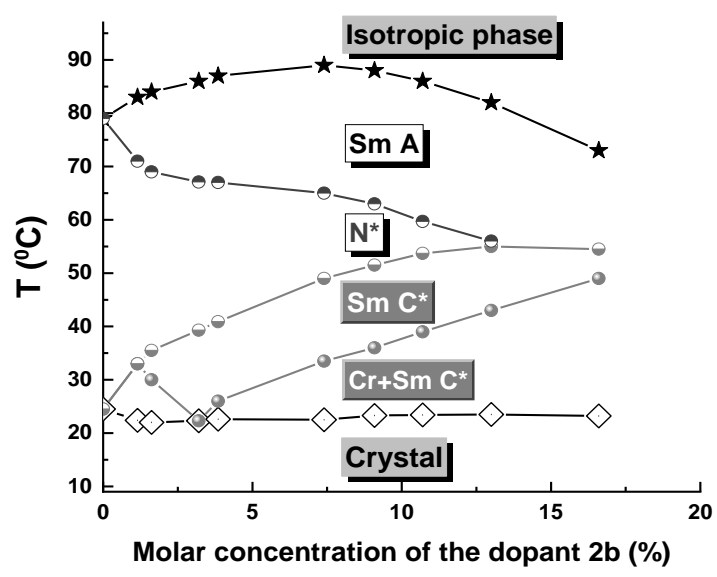

Fig. 2. Phase diagram of the ENLC matrix and chiral dopant 2b mixtures, obtained at heating from the crystal phase 
The phase diagram shows that at the dopant $\mathbf{2 b}$ concentration of $3.2 \mathrm{~mol}$. \% the eutectic mixture exists and the enantiotropic smectic $\mathrm{C}^{*}$ is induced at the temperature higher than $22.3{ }^{\circ} \mathrm{C}$. At the dopant 2a the phase diagram is very similar, but the eutectic mixture occurs when the concentration of $\mathbf{2 a}$ equals to $9.1 \mathrm{~mol}$. \%.

Evidently, at concentrations of the chiral dopant 2b different from the eutectic one, there is a wide temperature range of the two-phase region $\mathrm{Cr}+\mathrm{SmC}^{*}$ (Fig. 2). However, when mixtures are cooled from isotropic phase, the $\mathrm{SmC}^{*}$ phase exists in a supercooled state (without the two-phase region) till $+15^{\circ} \mathrm{C}$ usually within several days. This property allowed us to measure the main parameters of the induced $\mathrm{SmC}^{*}$ phase in a wide temperature range: the helix pitch, spontaneous polarization, rotational viscosity, and the tilt angle of molecules in smectic layers.

We have measured the temperature dependencies of the $\mathrm{SmC}^{*}$ mixtures helix pitch at various concentrations of the chiral dopant $2 \mathbf{b}$ (Fig. 3). In particular, for the ENLC eutectic mixture with chiral dopant $\mathbf{2 b}$ the helix pitch exceeds $150 \mathrm{~nm}$ at any temperature. Note that helix pitch $p_{0}=100 \mathrm{~nm}$ was measured at the concentration of $\mathbf{2 b}$ equal to $9.1 \mathrm{~mol}$. \% and at temperature $17{ }^{\circ} \mathrm{C}$.

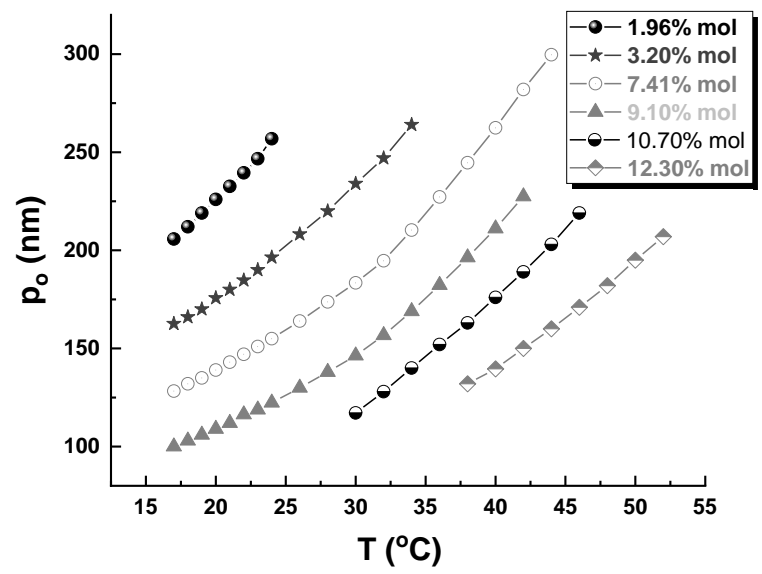

Fig. 3. Dependencies of the SmC* mixtures (ENLC matrix and chiral dopant 2b) helix pitch on chiral dopant concentration and temperature

One of the most informative characteristics of chiral dopants is their helical twisting power (HTP) [16]:

$$
H T P=\frac{1}{p_{0} c}
$$

where $c$ is a chiral dopant concentration. For the chiral dopant $\mathbf{2 b}$, at $c=9.09 \mathrm{~mol}$. $\%$ and temperature $17{ }^{\circ} \mathrm{C}$ HTP $\approx 109 \mu \mathrm{m}^{-1}$ that can be calculated by the formula (1) and the data shown in Fig. 3. For a comparison, the maximum HTP known before for chiral dopants was estimated as $46 \mu \mathrm{m}^{-1}$ [16]. Thus, in this work, a chiral dopant with the highest HTP known to date was synthesized.

The chiral dopant 2a exhibits HTP smaller than the dopant $\mathbf{2 b}$. HTP of $\mathbf{2 a}$ calculated at $\mathbf{c}=9.1 \mathrm{~mol}$. \% (eutectic point) is equal to $78 \mu \mathrm{m}^{-1}$. This value is confirmed by the data presented in Fig. 4, where $p_{0}=$ $140 \mathrm{~nm}$ at temperature $18{ }^{\circ} \mathrm{C}$.

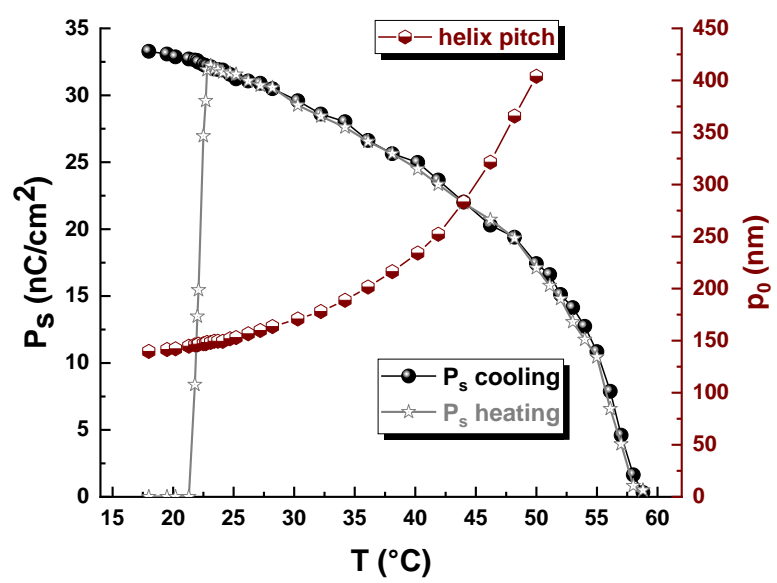

Fig. 4. Dependencies of the spontaneous polarization of the eutectic mixture (ENLC matrix and chiral dopant 2a) at heating from crystal to isotropic phase and cooling down. The helix pitch of the same mixture FLC-661 was measured on cooling

Fig. 4 also presents the temperature dependencies of spontaneous polarization upon heating and cooling of the eutectic mixture of the nonchiral nematic matrix ENLC and the chiral nonmesogenic compound 2a. Let us emphasize that this mixture (FLC-661) is the eutectic of three compounds: BPP-87, PP-608 and 2a. The eutectic of the mixture FLC-661 is confirmed both by a very narrow temperature interval of the phase transition from crystal to $\mathrm{SmC}^{*}$ phase $\left(1.8^{\circ} \mathrm{C}\right)$ and the absence of the temperature hysteresis of the spontaneous polarization (Fig. 4). FLC-661 has the maximum spontaneous polarization in enantiotropic $\mathrm{Sm} \mathrm{C*}$ phase near $32 \mathrm{nC} / \mathrm{cm}^{2}$. The $\boldsymbol{P}_{\boldsymbol{s}}$ value is approximately 1,5 times greater than the spontaneous polarization of the mixture NFLC-1, previously induced in the NLC matrix by a chiral non-mesogenic dopant [7]. 
The alignment quality of FLC-661 is illustrated in Fig. 5. It is obvious that the defects density is rather low, what characterizes the quite satisfactory optical quality of the $\mathrm{SmC}^{*}$ layer in the electro-optical cell.

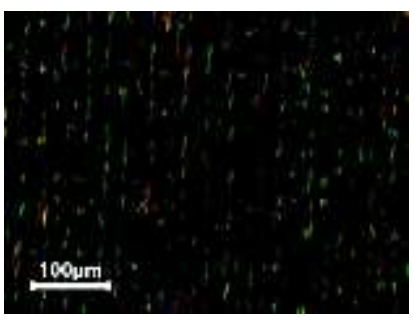

$a$

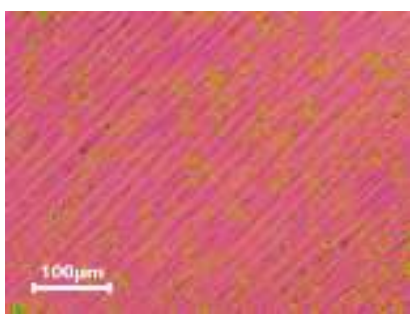

$b$
Fig. 5. Microphotographs of planar aligned FLC-661 6.7 $\mu \mathrm{m}$ thick layer textures taken by the polarizing microscope at $23{ }^{\circ} \mathrm{C}$ with crossed polarizer and analyzer. Rubbed $20 \mathrm{~nm}$ polyimide PMDA-ODA were used as aligning layers. $a-$ The helix axis is parallel to the polarizer plane, $b$ - the angle between the helix axis and the polarizer plane is $45 \mathrm{deg}$

Thus, FLC-661 developed by us combines all the necessary properties that allow it to be used in electro-optical devices operating on the basis of the DHF-electrooptical mode [8]. This SmC* material provides the electrooptical modulation up to the frequency of $3 \mathrm{kHz}$ (see Fig. 6) with the contrast ratio of about 45:1 in the white light.

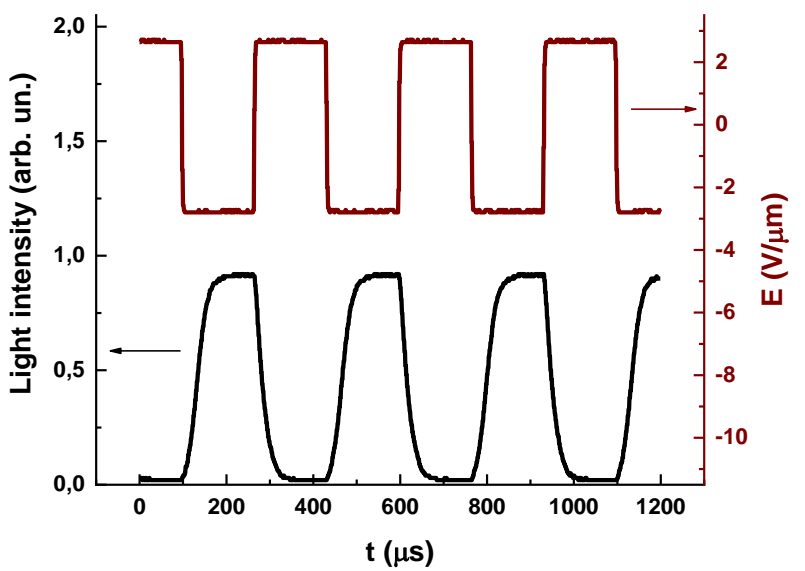

Fig. 6. Modulation of the white light intensity passing through the DHF cell filled with FLC-661 and placed between two crossed dichroic polarizers (bottom curve) under the electric field (top curve) applied to the cell. The cell gap is $6.7 \mu \mathrm{m}$, the temperature is $23{ }^{\circ} \mathrm{C}$

The eutectic mixture of ENLC with the chiral dopant $\mathbf{2 b}$ contains a very low concentration of the dopant (3.2 mol. \%). In order to compare the influence of the dopants $\mathbf{2 a}$ and $\mathbf{2} \mathbf{b}$ on the FLC mixtures properties, we prepared a mixture with the same content of dopant $\mathbf{2 b}$ equal to $9.1 \mathrm{~mol}$. \% (FLC-661/7) as in FLC-661. Temperature dependences of the rotational viscosity $\gamma_{\varphi}$ and the tilt angle $\theta$ of molecules in smectic layers for the mixture FLC-661/7 are presented in Fig. 7.

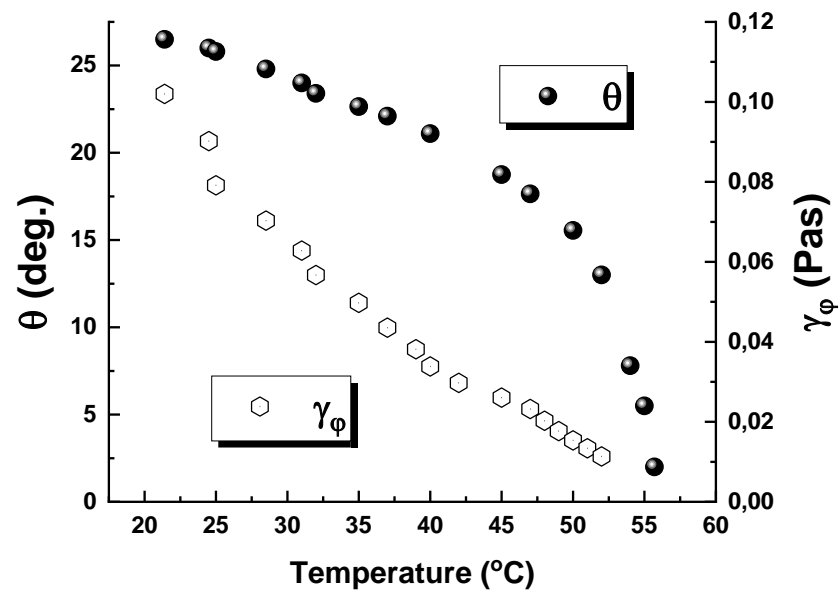

Fig. 7. Temperature dependences of tilt angle $\theta$ and rotational viscosity $\gamma_{\varphi}$ for the mixture FLC-661/7 in the cooling mode

It turned out that these dependencies on cooling from the isotropic phase are practically equivalent for the mixtures FLC-661/7 and FLC-661. The same can be said about the temperature dependencies of spontaneous polarization in the cooling regime from the isotropic phase $\left(\boldsymbol{P}_{\boldsymbol{s}}\right.$ of FLC-661 is presented in Fig. 4). On the other hand, the helical twisting power of the chiral dopant $\mathbf{2 b}$ is essentially higher with respect to 2a. Due to this, the helix pitch of the induced $\mathrm{SmC} *$ mixture FLC-661/7 reaches $100 \mathrm{~nm}$ (Fig. 3), while for FLC-661 it is $140 \mathrm{~nm}$ (Fig. 4).

\section{Conclusion}

In this work, two new chiral compounds were synthesized: bis[(1S)-1-methyl-2-\{[(1S)-1-methylheptyl]oxy\}-2-oxoethyl] 1,1':4',1"-terphenyl-4,4"-dicarboxylate (2a) and bis[(1S)-1-methyl-2-\{[(1S)-1methyloctyl]oxy\}-2-oxoethyl]1,1':4',1"-terphenyl-4,4"dicarboxylate (2b). These compounds were used as chiral dopants to induce a chiral $\mathrm{SmC}^{*}$ phase by introducing them into a specially designed eutectic nematic matrix. As a result, for the first time, we suc- 
ceeded to induce a ferroelectric $\mathrm{SmC}^{*}$ phase with a subwavelength helix pitch of the order of 100-150 nm in a nematic matrix. It was experimentally proved that dopants $2 \mathbf{a}$ and $\mathbf{2 b}$ possess the highest known helical twisting power: $78 \mu \mathrm{m}^{-1}$ and $109 \mu \mathrm{m}^{-1}$, respectively. The electro-optical cells based on the elaborated mixtures manifest a satisfactory optical quality of the induced $\mathrm{SmC}^{*}$ and can efficiently operate at frequencies up to $3 \mathrm{kHz}$ in DHF mode.

\section{Acknowledgments}

The work was partially supported by the following RFBR grants: № 19-52-06005 MNTI a and № 20-02-00746 A. The authors are grateful to Dr. V. Vashchenko (Hong Kong University of Science and Technology), for his useful ideas and discussions.

\section{References}

1. Clark N.A. and Lagerwall S.T. Submicrosecond bistable electro-optic switching in liquid crystals. Appl. Phys. Lett., 1980, 36, 899-901. DOI: 10.1063/1.91359.

2. Srivastava A.K., Pozhidaev E.P., Chigrinov V.G., Manohar R. Single-Walled Carbon Nano-tube, Ferroelectric Liquid Crystal Composites: Excellent Diffractive Tool. Appl. Phys. Lett., 2011, 99, 201106. DOI: $10.1063 / 1.3661170$.

3. Pozhidaev E.P., Srivastava A.K., Kiselev A.D., Chigrinov V.G., Vashchenko V.V., Krivoshey A.I., Minchenko M.V., and Kwok H.S. Enhanced orientational Kerr effect in vertically aligned deformed helix ferroelectric liquid crystals. Opt. Lett., 2014, 39, 2900-2903. DOI: 10.1364/OL.39.002900.

4. Kuczynski W. and Stegemeyer H. Ferroelectric properties of smectic C liquid crystals with induced helical structure. Chem. Phys. Lett., 1980, 70 (1), 123126. DOI: $10.1016 / 0009-2614(80) 80075-3$.

5. Beresnev L.A., Pozhidaev E.P., Blinov L.M., Pavlyuchenko A.I., Etingen N.B. A liquid crystal ferroelectric with a record spontaneous polarization. JETP Letters, 1982, 35 (10), 531-534.

6. Stegemeyer H., Meister R., Altenbach H.-J., Szewczyk D. Ferroelectricity of induced smectic $\mathrm{C}^{*}$ phases. J. Mater. Chem., 1995, 5 (12), 2183-2193.

DOI: $10.1039 /$ JM9950502183.

7. Pozhidaev E.P., Torgova S.I., Barbashov V.A., Minchenko M.V., Sulyanov S.N., Dorovatovskii P.V., Ostrovskii B.I., and Strigazzi A. Ferroelectric C* phase induced in a nematic liquid crystal matrix by a chiral non-mesogenic dopant. Appl. Phys. Lett., 2015, 106, 062904. DOI: $10.1063 / 1.4908152$.
8. Beresnev L.A., Chigrinov V.G., Dergachev D.I., Poshidaev E.P., Funfshilling J., Schadt M. Deformed helix ferroelectric liquid crystal display - a new electrooptic mode in ferroelectric smectic $C^{*}$ liquid crystals. Liquid Crystals, 1989, 5 (4), 1171-1177.

DOI: $10.1080 / 02678298908026421$.

9. Pozhidaev E., Chigrinov V., Murauski A., Molkin V., Tao D., Kwok H.S. V-shaped electrooptical mode based on deformed-helix ferroelectric liquid crystal with subwavelength pitch. Journal of the SID, 2012, 20 (5), 273-278. DOI: 10.1889/JSID20.5.273.

10. Zhang Y.S., Liu C.Y., Emelyanenko A.V., Liu J.H. Synthesis of Predesigned Ferroelectric Liquid Crystals and Their Applications in Field-Sequential Color Displays. Adv. Funct. Mater., 2018, 28, 1706994.

DOI: $10.1002 / \mathrm{adfm} .201706994$.

11. Srivastava A.K., Pozhidaev E.P., Chigrinov V.G., Kwok H.S. Vertically aligned ferroelectric liquid crystals with high Kerr constant for field sequential color displays. Journal of Molecular Liquids, 2019, 295, 111054. DOI: 10.1016/j.molliq.2019.111054.

12. Kotova S., Pozhidaev E., Samagin S., Kesaev V., Mayorova A. Ferroelectric liquid crystals with subwavelength helix nanostructure pitch for the generation of axial-symmetric vortex light fields. EPJ Web of Conferences, 2019, 220, 01005.

DOI: $10.1051 /$ epjconf/201922001005.

13. Haase W., Suvorova A., Chernyaev I., Kundikova N., Pozhidaev E., and Podgornov F. Light Polarization Modulation with Ferroelectric Liquid Crystals. Integrated Ferroelectrics, 2007, 87 (3-12), 657-666. DOI: $10.1080 / 10584580601099124$.

14. Kiselev A.D., Kesaev V.V., Pozhidaev E.P. Orientational Kerr effect in liquid crystal ferroelectrics and modulation of partially polarized light. Journal of Physics: Conference Series, 2018, 1092, 012056.

DOI: $10.1088 / 1742-6596 / 1092 / 1 / 012056$.

15. Dultz W., Ganzke D., Haase W., Pozhidaev E, Device and method for the temperature-independent operation of electro-optical switchers on the basis of ferroelectric liquid crystals having a deformed helix. US patent 6,900,874 B1. 2005.

16. Mikhailenko V., Krivoshey A., Pozhidaev E., Popova E., Fedoryako A., Gamzaeva S., Barbashov V., Srivastava A.K., Kwok H.S., Vashchenko V. The nano-scale pitch ferroelectric liquid crystal materials for modern display and photonic application employing highly effective chiral components: Trifluoromethylalkyl diesters of $p$ terphenyldi-carboxylic acid. Journal of Molecular Liquids, 2019, 281, 186-195.

DOI: $10.1016 /$ j.molliq.2019.02.047. 
17. Mikhailenko V.V., Popova E.V., Gamzaeva S.A., Pozhidaev E.P., Vashchenko V.V. Induced helical nanostructures in ferroelectric liquid crystals. Intern. Research and Practice Conf. "Nanotechnology and nanomaterials ( NANO-2016)»: abstract book. Ukraine, Lviv, 24-27 August, 2016, p. 610.

18. Patent of Ukraine UA № 119903 C2. Bis ((S)-1-(((S)alkan-2-yloxy)carbonyl)ethyl)-4,4"-terphenyldicarboxylate bis(S)-1-(((R)-alkan-2-yloxy)carbonyl)ethyl)4,4"-terphenyldicarboxylate ferroelectric liquid crystal compositions / A.I. Krivoshey, V.V. Mikhailenko, V.V. Vashchenko; request № a 2017 08371; declared 14.08.2017; publ. 27.08.2019; Bull. «Industrial Property» № 16, 19 p. (in Ukrainian).

19. Cambell T.W. Dicarboxylation of Terphenyl. J. Am. Chem. Soc., 1960, 82, 3126-3128.

DOI: $10.1021 / \mathrm{ja} 01497 \mathrm{a} 035$.

20. Zhukov A.A., Pozhidaev E.P., Bakulin A.A., Babaevskiı̌ P.G. Energy criteria for orientation of smectic C* liquid crystals in electrooptic elements. Crystallography Reports, 2006, 51 (4), 680-684.

DOI: $10.1134 / \mathrm{S} 1063774506040237$.

21. Pozhidaev E., Friere F.C.M., Yednak C.A.R., Strigazzi A., Torgova S., Molkin V., Minchenko M. Permittivity of Chiral Smectics in the Broad Range from $0.1 \mathrm{mHz}$ to $50 \mathrm{kHz}$ : Discovery of Sub-mHz Dielectric Dispersion. Mol. Cryst. Liq. Cryst., 2011, 546, Sp. Iss. SI, 186-194. DOI: $10.1080 / 15421406.2011 .571151$.
22. Pozhidaev E.P., Kiselev A.D., Srivastava A.K., Chigrinov V.G., Kwok H.S., Minchenko M.V.. Orientational Kerr effect and phase modulation of light in deformed-helix ferroelectric liquid crystals with subwavelength pitch. Phys. Rev. E, 2013, 87, 052502. DOI: $10.1103 /$ PhysRevE.87.052502.

23. Hori K. Angular Dependence of Selective Reflection from the Chiral Smectic C Phase. Mol. Cryst. Liq. Cryst., 1982, 82, 13-17.

DOI: $10.1080 / 01406568208070506$.

24. Panov V., Vij J. K., Shtykov N.M. A field-reversal method for measuring the parameters of a ferroelectric liquid crystal. Liquid Crystals, 2001, 28 (4), 615-620. DOI: $10.1080 / 02678290010020175$.

25. Barnik M.I., Baikalov V.A., Chigrinov V.G., Pozhidaev E.P. Electro-optics of a thin ferroelectric smectic C* liquid crystalline layer. Mol. Cryst. Liq. Cryst., 1987, 143, 101-112. DOI: 10.1080/15421408708084615.
Поступила 13.08.2020 2. Received 13.08.2020

Принята 28.08.2020 2. Accepted 28.08.2020 